\title{
ANALISIS KEUNTUNGAN INTEGRASI USAHA TERNAK BABI DENGAN IKAN MUJAIR DI KECAMATAN SONDER KABUPATEN MINAHASA
}

\author{
Dalton R. Abraham; M. A. V. Manese*); L. W. Sondakh*); Nansi M. Santa*) \\ Fakultas Peternakan Universitas Sam Ratulangi Manado, 95115.
}

\begin{abstract}
ABSTRAK
Kecamatan Sonder merupakan salah satu kecamatan yang ada di Kabupaten Minahasa dengan luas wilayah 5.672,2 ha. Umumnya masyarakat di Kecamatan Sonder berprofesi sebagai petani/peternak. Populasi ternak babi di Kecamatan Sonder sebesar 5.963 ekor yang tersebar di 10 desa. Masalah dalam penelitian ini adalah bagaimana peternak mengelola usaha ternak babi yang diintegrasikan dengan ikan mujair dan berapa keuntungan usaha ternak babi tersebut. Penelitian ini dilaksanakan di Kecamatan Sonder pada 2 desa yaitu desa Talikuran dan desa Kauneran dari tanggal 16 Oktober sampai 20 November 2012 dengan jumlah responden sebanyak 30 orang. Metode pengumpulan data menggunakan metode survei. Metode penentuan sampel ditentukan secara sengaja dengan pertimbangan memiliki populasi ternak babi terbanyak. Hasil dari penelitian menunjukkan bahwa keuntungan integrasi usaha ternak babi dengan ikan mujair sebesar Rp 198.188.000/periode produksi dengan rata-rata $\operatorname{Rp~6.606.267/responden.~}$
\end{abstract}

\section{Kata Kunci:Integrasi, Usaha Ternak Babi, Ikan Mujair}

\section{ABSTRACT}

PROVITABILITY ANALISYS OF
INTEGRATED FARMING
BETWEENPIG AND MUJAIR FISH ON
SONDER SUB-DISTRICTMINAHASA
REGENCY. Sonder sub district was
located in Minahasa regency with the

*Dosen Pembimbing region area up 5.672,2 ha. The peoples in this area used to cultivate their land or raise livestock as common activity. There was 5.963 heads of pig spread over ten vellages. The aim of this research were to find out the method performed by farmers in combining pig and mujair fish as intergrated farming and its provitability. Research was conducted in two vellages consist of Talikuran and Kauneran. Data collection was focused on 30 farmers as respondents. The research area was chosen by purpossive random sampling methode because it had most pig population in amount. The result of the study indicated that integrated farming system between pig and mujair fish was profitable because farmers gained net in come Rp 198.188.000/periode and Rp 6.606.267/respondent in averages.

\section{Keywords: Integrated, Pig Farming, Mujair Fish PENDAHULUAN}

Peternakan merupakan salah satu sub sektor pertanian yang berperan penting dalam menunjang kebutuhan masyarakat sebagai sumber protein hewani. Usaha ternak babi merupakan salah satu usaha peternakan yang dapat menyediakan sumber protein hewani dalam bentuk daging.

Pengelolaan usaha ternak babi berhubungan erat dengan sumberdaya yang dimiliki oleh peternak dalam menjalankan usahanya. Sumberdaya dapat berupa modal untuk membiayai proses produksi dan keterampilan beternak yang merupakan kendala 
dalam berusaha ternak babi. Peternak diperhadapkan pada pengambilan keputusan dalam proses produksi dengan memperhitungkan biaya produksi. Hal ini disebabkan karena biaya produksi berhubungan dengan jumlah yang akan diproduksi. Dengan kata lain biaya produksi merupakan faktor penentu dalam produksi ternak (Rahardi, dkk. 2003).

Perhatian masyarakat terhadap beternak babi cukup besar karena tujuan memelihara ternak babi selain untuk memenuhi kebutuhan daging bagi masyarakat juga menambah penghasilan keluarga. Apabila dikelola dengan baik, usaha ternak babi dapat memberikan keuntungan bagi peternak, karena ternak babi dapat dijual pada umur lepas sapih (5-6 minggu) dan 8-9 bulan dengan bobot berat badan $90-110 \mathrm{~kg}$. Selain itu, siklus reproduksi serta laju pertumbuhan ternak babi relatif cepat dan membutuhkan perhatian dalam aspek tatalaksana pemeliharaan serta pemberian pakan.

Usaha ternak babi yang dipelihara di pemukiman penduduk dapat menimbulkan permasalahan lingkungan. Permasalahan yang paling sering terjadi adalah kesulitan pembuanganlimbah ternak babi yang dapat berupa kotoran ternak dan sisasisa pakan ternak yang terbuang. Sisa pakan yang terbuang dan berada di kandang ternak mengakibatkan berkembangnya bakteri serta menimbulkan penyakit ternak. Selain itu, sisa pakan tersebut dapat mengurangi pendapatan yang diperoleh (Santa, 2011).

Kecamatan Sonder merupakan salah satu kecamatan yang ada di Kabupaten Minahasa yang mempunyai potensi sebagai daerah pengembangan usaha peternakan babi. Populasi ternak babi di Kecamatan Sonder pada tahun 2010 berjumlah 18,930 ekor yang terdiri dari jantan 1.937 ekor dan betina 16.993 ekor. Tujuan penelitian ini untuk menganalisis keuntungan integrasi usaha ternak babi dengan ikan mujair.

\section{MATERI DAN METODE PENELITIAN}

Penelitian ini dilaksanakan di Kecamatan Sonder dari tanggal 16 Oktober 2012 sampai dengan 20 November 2012.Data dalam penelitian ini dikumpulkan dengan menggunakan metode survei. Metode survei merupakan suatu teknikpengumpulaninformasi yang dilakukan dengan cara menyusun daftarpertanyaan yang diajukan pada peternak babi di Kecamatan Sonder.

Jenis data yang digunakan dalam penelitian ini yaitu data primer dan sekunder. Data primer meliputi data yang diperoleh melalui wawancara langsung dengan responden yang berpedoman pada daftar pertanyaan (kuesioner) yang telah disediakan serta melakukan teknik observasi dengan mengamati secara langsung dilokasi penelitian di Kecamatan Sonder. Data sekunder meliputi data yang diperoleh dari lembaga atau instansi yang terkait antara lain kantor Dinas Kehewanan Kabupaten Minahasa, kantor Dinas Kecamatan Sonder, BP3K (Balai Penyuluhan Pertanian Peternakan Kecamatan Sonder) dan dari Kantor Desa.

Metode penentuan sampel dilakukan dalam dua tahap. Tahap pertama penentuan lokasi yaitu desa sampel yang ditentukan secara sengaja dengan pertimbangan memiliki 
jumlahpopulasi ternak babi terbanyak(Singaribun dan Effendi, 2011).

Berdasarkan pertimbangan tersebut, maka dipilih dua desa yaitu Desa Talikuran dan Desa Kauneran. Tahap kedua yaitu penentuan responden menentukan peternak sebagai responden sebagai berikut:

1. memiliki minimal 2 ekor induk.

2. lama usaha lebih dari 1 tahun.

3. peternak yang memelihara ikan mujair.

Pengertian dan batasan-batasan variabel yang digunakan dalam penelitian ini, ialah:

1. Penerimaan usaha ternak babi ialah penerimaan yang diterima petani peternak dari hasil penjualan ternak babi dihitung dalam Rp/periode produksi (satu periode produksi sembilan (9) bulan).

2. Penerimaan usaha ikan mujair ialah penerimaan yang diterima petani peternak dari hasil penjualanikan mujairdihitung dalam Rp/periode produksi (satu periode produksi tiga (3) bulan).

3. Keuntungan usaha ternak babi ialah hasil yang diterima dari selisih penerimaan dan seluruh biaya yang dikeluarkan peternak dihitung dalam Rp/periode produksi.

4. Keuntungan usaha ikan mujair ialah hasil yang diterima dari selisih penerimaan dan seluruh biaya yang dikeluarkan peternak dihitung dalam Rp/periode produksi.

5. Biaya adalah biaya yang dikeluarkan dalam produksi pada masing-masing usaha meliputi biaya tetap dan biaya tidak tetap, dihitung dalm Rp/periode produksi.

6. Biayatetapusahaternakbabiialahbia ya yang dikeluarkansaatmemeliharaternakb abiyaitupenyusutankandangdanper alatandihitung dalam Rp/periode produksi (satu periode produksi sembilan (9) bulan).

7. Biayatetapusahaikanmujairialahbia ya yang dikeluarkansaatmemeliharaikanmu jairyaituperalatandihitung dalam $\mathrm{Rp} /$ periode produksi (satu periode produksi tiga (3) bulan).

8. Biayatidaktetapusahaternakbabiial ahbiayaoperasionaldalam proses pemeliharaanternakbabiyaitubiaya pakan, biayavitamin, danbiayatenagakerjadihitungdalam $\mathrm{Rp} /$ periode produksi (satu periode produksi sembilan (9) bulan).

9. Biayatidaktetapusahaikanmujairial ahbiayaoperasionaldalam proses pemeliharaanikanmujairyaitubiaya tenagakerjadihitungdalamRp/perio de produksi (satu periode produksi tiga (3) bulan).

Model analisis data yang digunakanyaitu yang pertamapendekatananalisisdeskriptif.

Model yang keduamenggunakan rumus analisis keuntungan menurut Soekartawi (2003).

a. Keuntungan ternak babi

$$
\begin{aligned}
\mathrm{K}_{\mathrm{tb}}= & \operatorname{PrT}_{\mathrm{tb}}-\mathrm{B}_{\mathrm{tb}} \\
& =\operatorname{PrT}_{\mathrm{tb}}-\left(\mathrm{BT}_{\mathrm{tb}}+\mathrm{BTT}_{\mathrm{tb}}\right)
\end{aligned}
$$

Keterangan:

$\mathrm{K}_{\mathrm{tb}}=$ Keuntungan Ternak Babi (Rp/periode produksi).

$\operatorname{PrT}_{\mathrm{tb}}=$ Penerimaan Total Ternak Babi (Rp/periode produksi). 
$\mathrm{BT}_{\mathrm{tb}}=\quad$ Biaya Tetap Ternak Babi (Rp/periode produksi).

$\mathrm{BTT}_{\mathrm{tb}}=$ Biaya Tidak Tetap Ternak Babi (Rp/periode produksi).

b. Keuntungan mujair

$\mathrm{K}_{\mathrm{im}}=\operatorname{PrT}_{\mathrm{im}}-\mathrm{B}_{\mathrm{im}}$

$=\operatorname{PrT}_{\mathrm{im}}-\left(\mathrm{BT}_{\mathrm{im}}+\mathrm{BTT}_{\mathrm{im}}\right)$

Keterangan:

$\mathrm{K}_{\mathrm{im}}=$ Keuntungan Ikan Mujair ( $\mathrm{Rp} /$ periode produksi).

$\mathrm{PrT}_{\mathrm{im}}=$ Penerimaan Total Ikan Mujair (Rp/periode produksi).

$\mathrm{BT}_{\mathrm{im}}=$ Biaya Tetap Ikan Mujair (Rp/periode produksi).

BTT $_{\text {im }}=$ Biaya Tidak Tetap Ikan Mujair (Rp/periode produksi).

c. Keuntungan ternak babi dengan ikan mujair

$\mathrm{K}_{\mathrm{tb}}-\mathrm{K}_{\mathrm{im}}=\operatorname{PrT}_{\mathrm{tb}}+\operatorname{PrT}_{\mathrm{im}}-\left(\mathrm{BT}_{\mathrm{tb}}+\mathrm{BT}_{\mathrm{im}}\right.$ $\left.+\mathrm{BTT}_{\mathrm{tb}}+\mathrm{BTT}_{\mathrm{im}}\right)$

Keterangan:

$\mathrm{K}_{\mathrm{tb}}-\mathrm{K}_{\mathrm{im}}=$ Keuntungan Ternak Babi Di integrasikan Dengan Ikan Mujair

$\operatorname{PrT}_{\mathrm{tb}} \quad=$ Penerimaan Total

Ternak Babi (Rp/periode produksi).

$\mathrm{BT}_{\mathrm{tb}} \quad=$ Biaya Tetap Ternak Babi (Rp/periode produksi).

$\mathrm{BTT}_{\mathrm{tb}} \quad=\quad$ Biaya Tidak Tetap Ternak Babi (Rp/periode produksi).

$\operatorname{PrT}_{\mathrm{im}} \quad=$ Penerimaan Total Ikan Mujair (Rp/periode produksi).

$\mathrm{BT}_{\text {im }}=$ Biaya Tetap Ikan Mujair (Rp/periode produksi).

BTT $_{\text {im }}=$ Biaya Tidak Tetap Ikan Mujair (Rp/periode produksi).

\section{HASIL DAN PEMBAHASAN}

\section{Keadaan Umum Daerah Penelitian}

Wilayah Kecamatan Sonder merupakan salah satu kecamatan yang ada di kabupaten Minahasa terletak antara $1^{0}-11^{0}$ Lintang Utara, $64^{0}-$ $123^{0}$ Bujur Timur. Wilayah Kecamatan Sonder terletak kurang lebih $40 \mathrm{~km}$ sebelah selatan ibukota Propinsi Sulawesi Utara dan $20 \mathrm{~km}$ dari ibukota Kabupaten Minahasa. Kecamatan Sonder memiliki 10 desa yaitu; Leilem, Kolongan Atas, Kauneran, Talikuran, Sendangan, Rambunan, Sawangan, Tincep, Timbukar dan Taunelet.

\section{Karakteristik Responden}

\section{Umur}

Salah satu faktor yang mempengaruhi kemampuan dan kemauan seseorang dalam berusaha ialah umur. Hal ini sesuai dengan pendapat Soekartawi (2003) bahwa, pada umur muda biasanya seseorang mempunyai semangat ingin tahu apa yang mereka belum ketahui dengan demikian mereka berusaha lebih cepat melakukan adopsi inovasi walaupun sebenarnya mereka belum berpengalaman dalam soal adopsi tersebut. Hasil penelitian menunjukkan bahwa kelompok umur 20-30 tahun sebanyak 2 responden (6,67 persen), 31-40 sebanyak 14 responden (46,67 persen), 41-50 sebanyak 10 responden (33,33 persen) dan umur $>50$ sebanyak 4 responden (13,33 persen). 


\section{Pendidikan}

Pendidikan merupakan salah
satu sarana penunjang dalam pembangunan baik sektor pertanian, sektor industri dan jasa. Pendidikan dari seseorang akan mempengaruhi cara berpikir sehingga dalam bekerja mereka memperhitungkan perkerjaan yang menguntungkan dan merugikan (Soekartawi, 2002). Hasil penelitian menunjukkan bahwa sebagian besar responden berpendidikan SMA yaitu sebesar 18 persen, SMP 26,67 persen, perguruan tinggi 16,67 persen dan SD 6,67 persen.

\section{Lama Usaha}

Pengalaman dalam suatu usaha merupakan salah satu faktor penentu keberhasilan, dimana faktor pengalaman sangat ditentukan oleh lamanya usaha. Peternak yang menjalankan usaha ternak babi 1-10 tahun berjumlah 9 responden (30 persen), 11-20 tahun berjumlah 13 responden (43,33 persen) dan 21-30 sebanyak 8 responden (26,67 persen).

\section{Pekerjaan}

Hasil penelitian menunjukkan bahwa sebagian pekerjaan responden adalah petani dan peternak sebayak 21 responden (70 persen), kemudian peternak yang bekerja sebagai pedagang sebanyak 3 responden (10 persen) dan peternak yang bekerja sebagai pegawai sebanyak 6 responden (20 persen).

\section{Usaha Peternakan Babi Di Kecamatan Sonder}

\section{Jenis Ternak Babi}

Berdasarkan hasil penelitian menunjukkanbahwa, jenis bangsa babi peliharaan adalah babi Duroc dan babi Landrace. Williamson and Payne (2002) menyatakanbahwababiLandracemerup akanhasilpersilanganantarapejantan $L a$ rge Whitedenganinduklokal.Menurut Blakely and Bade (2007) babiiniberasaldari Denmark danmerupakanbabi bacon yang berkualitastinggi.

Ciri-ciri ternak Babi Duroc ialah; tubuh panjang dan besar, warna merah tua, punggung berbentuk busur yang dimulai dari leher sampai ekor dengan titik tertinggi ditengah-tengah, ukuran kepala sedang dan muka agak cekung serta produksi susu cukup baik dan banyak anak. Ternak babi jenis Landrace mempunyai ciri-ciri; tubuh panjang, besar dan lebar, warna putih dengan bulu yang halus, kepala kecil agak panjang, dengan telinga terkulai, leher panjang, punggung membentuk seperti busur, panjang dan lebar, kaki letaknya baik dan kuat (Sinaga, 2010).

\section{Kandang dan Perlengkapan}

Kandang merupakan hal yang sangat penting dalam menunjang keberhasilan usaha, karena kandang berfungsi untuk melindungi ternak terhadap hujan dan panas sinar matahari, serangan binatang buas, pencuri dan untuk memudahkan tatalaksana seperti pemberian pakan, membersihkan kandang, memandikan babi dan pengontrolan penyakit (Sinaga, 2012).

Berdasakan hasil pengamatan dilokasi penelitian, kondisi lingkungan sekitar kandang babi terdapat sungai. Tempat kedudukan kandang babi milik peternak berada di dekat sungai di belakang rumah penduduk. 
Kontruksi kandang babi permanen berlantai beton, beratapkan seng dan di samping kandang terdapat bak untuk pembuangan limbah serta sisasisa makanan ternak babi. Peralatan yang ada pada peternak umumnya terdiri dari: sapu pembersih, ember, sekop, kabel listrik dan selang air. Tetapi ada juga beberapa peternak sudah memiliki alat timbangan.

\section{Pakan Ternak}

Pakan ternak atau ransum merupakan faktor produksi utama dalam usaha ternak babi karena mempengaruhi pertumbuhan dan produksi. Hasil penelitian menunjukkan pemberian pakan untuk ternak babi dilakukan 2 kali sehari. Pakan yang diberikan untuk ternak babi ialah jagung, dedak atau biasa disebut konga, konsentrat dan vitamin (pigmix).

\section{Sisitem Pemeliharaan}

Sistem pemeliharaan ternak babi di lokasi penelitian menunjukkan bahwa, anak babi yang baru lahir segera ditolong dan dibersihkan selaput lendir yang menutup tubuhnya, terutama lubang mulut dan hidung. Selanjutnya dilakukan pemotongan tali pusar, dari bekas luka pemotongan diberikan disinfektan berupa betadin. Anak babi yang berumur 1 hari segera mendapat kolostrum yang kaya antibodi dan anak babi yang baru lahir dituntun untuk menyusui. Pemisahan anak babi dilakukan peternak pada umur 7-8 minggu.

\section{Biaya Usaha Ternak Babi}

Penggunaan biaya dalam usaha ini meliputi biaya tetap dan biaya tidak tetap. Biaya tetap meliputi: biaya penyusutan kandang/peralatan (ember, sekop dan selang air), Sedangkan biaya tidak tetap meliputi: biaya pakan, vitamin dan upah tenaga kerja. Rata-rata komposisi biaya tetap per responden berjumlah Rp.77.000/periode produksi dan ratarata komposisi biaya tidak tetap per responden berjumlah Rp.7.892.500/periode produksi. jadi, rata-rata komposisi biaya tetap dan tidak tetap per responden berjumlah Rp.7.969.500/periode produksi.

\section{Usaha Ikan Mujair}

\section{Jenis Ikan Mujair}

Jenis ikan mujair yang dikenal antara lain: mujair biasa, mujair merah (mujarah) atau jamerah dan mujair albino.

IkaniniberasaldariperairanAfrikadanpe rtama kali di Indonesia ditemukanolehbapakMujair di muarasungaiSerangpantaiselatanBlitar JawaTimurpadatahun 1939 (Rahardi, 2003).Berdasarkan hasil penelitian bahwa, ikan mujair yang dipelihara ialah jenis mujair biasa dengan ciriciri, bentuk badan pipih dengan warna abu-abu, coklat atau hitam.

\section{Kolam dan Perlengkapan}

Hasil penelitian menunjukkan bahwa kolam di lokasi penelitian terbagi 2 yaitu, (1) kolam pembesaran, yang berfungsi sebagai kolam pemeliharaan induk dan juga sebagai pemeliharaan benih; (2) kolam pemberokan, yang berfungsi sebagai tempat pembersihan ikan sebelum dipasarkan. Alat yang digunakan dalam usaha perikanan ikan mujair ialah, jala yang berfungsi untuk menangkap ikan mujair.

\section{Pakan Ikan Mujair}


Hasil penelitian menunjukkan bahwa pakan ikan mujair hanya berupa sisa-sisa makanan dan kotoran atau limbah dari ternak babi.

\section{Sistem Pemeliharaan Ikan Mujair}

Hasil penelitian menunjukkan bahwa sistem pemeliharaan ikan mujair yaitu ikan mujair dibiarkan begitu saja tanpa adanya penanganan khusus, baik dalam hal pakan maupun dalam penanganan hama dan penyakit. Hal yang dilakukan hanya pengontrolan saluran air/saluran pembuangan.

\section{Biaya Usaha Ikan Mujair}

Hasil penelitian menunjukkan bahwa penggunaan biaya dalam usaha ini meliputi biaya tetap dan biaya tidak tetap. Biaya tetap meliputi biaya perlengkapan (jala) sebesar Rp. 1.350.000, dengan rata-rata Rp.45.000/responden. Sedangkan untuk biaya tidak tetap meliputi upah tenaga kerja sebesar Rp 14.100.000, dengan rata-rata $\mathrm{Rp}$. 470.000/responden. Total biaya usaha ikan mujair selama 3 periode sebesar Rp. 15.450.000 dengan rata-rata Rp. 515.000/responden.

\section{Pola Integrasi Usaha Ternak Babi Dengan Ikan Mujair}

Pola integrasi usaha ternak babi dan ikan mujair di lokasi penelitian dapat dilihat seperti pada Gambar 1. 


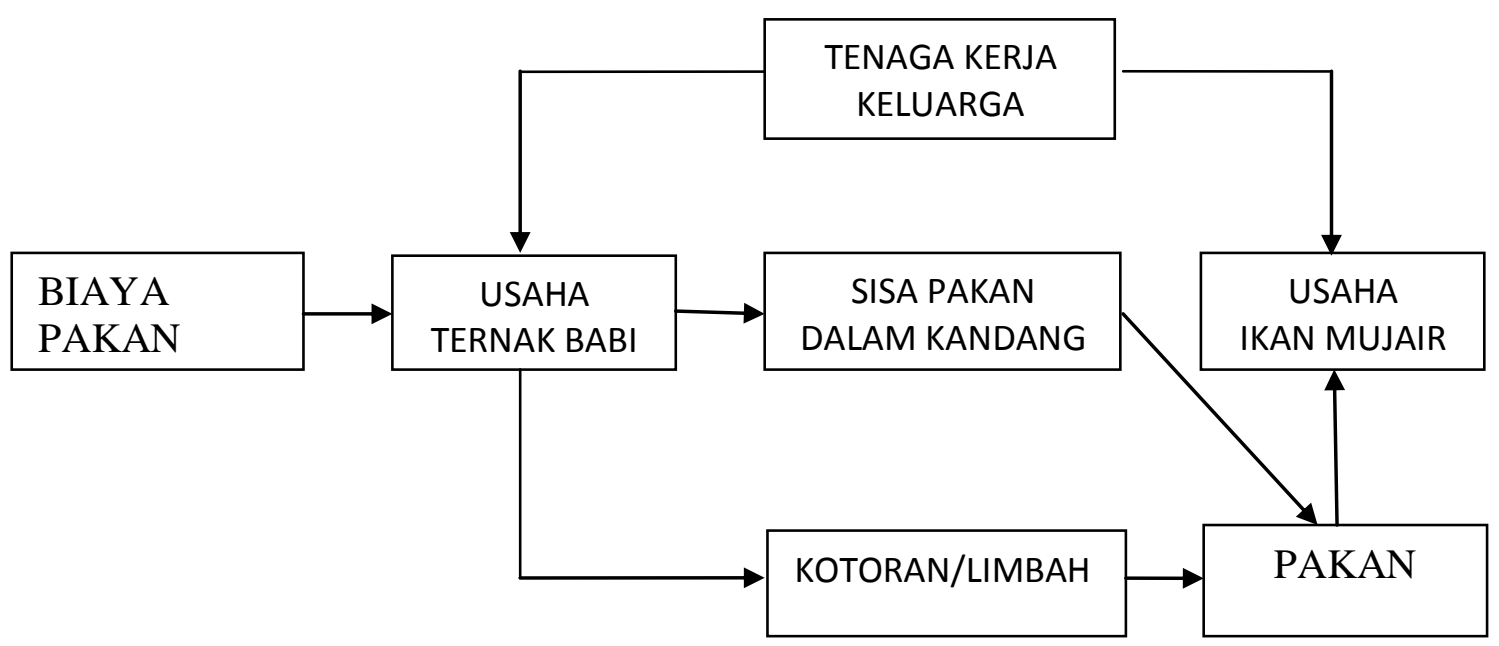

Gambar 1.Pola Integrasi Usaha Ternak Babi dengan Ikan Mujair Di Kecamatan Kecamatan Sonder

Gambar 1 menunjukkan bahwa, pada usaha ternak babi diperlukan biaya pakan, sedangkan pada usaha ikan mujair tidak memerlukan biaya pakan, hanya sisa pakan dan kotoran/limbah dari kandang babi. Sisa-sisa pakan ternak babi itulah yang dijadikan pakan untuk ikan mujair. Pada integrasi usaha ternak babi dengan ikan mujair faktor tenaga kerja keluarga digunakan secara bersamaan dalam mengelola usaha ternak babi dengan usaha ikan mujair.

Hasil penelitian menunjukkan bahwa pada pola integrasi usaha ternak babi dengan ikan mujair, sistem pembuangan sisa pakan dan limbah/kotoran ternak babi tidak langsung dialirkan dimana tempat pemeliharaan ikan mujair. Tetapi, sisa pakan dan limbah/kotoran ternak babi dialirkan terlebih dahulu ke got/selokan yang terletak diantara kandang babi dengan kolam tempat pemeliharaan ikan mujair. Kolam tempat pemeliharaan ikan mujair bukanlah kolam yang airnya tenang seperti kolam-kolam pada umumnya, tetapi kolam tempat pemeliharaan ikan mujair ini adalah kolam yang airnya deras.

\section{Analisis Keuntungan.}

Berdasarkan hasil perhitungan keuntungan usaha ternak babi di wilayah penelitian sebesar Rp.179.213.000/periode produksi, dengan rata-rata sebesar Rp.5.974.000/responden. Sedangkan keuntungan usaha ikan mujair sebesar Rp.18.975.000, dengan rata-rata sebesar Rp.632.500/responden. Keuntungan integrasi usaha ternak babi dengan ikan mujair yaitu:

Keuntungan Ternak Babi-Ikan Mujair

$$
\begin{aligned}
\mathrm{K}_{\mathrm{tb}}-\mathrm{K}_{\mathrm{im}}= & \operatorname{PrT}_{\mathrm{tb}}+\operatorname{PrT}_{\mathrm{im}}-\left(\mathrm{BT}_{\mathrm{tb}}+\right. \\
& \left.\mathrm{BT}_{\mathrm{im}}+\mathrm{BTT}_{\mathrm{tb}}+\mathrm{BTT}_{\mathrm{im}}\right)
\end{aligned}
$$


Keuntungan ternak babi $\leftrightarrow$ ikan mujair

$\mathrm{K}_{\mathrm{tb}}-\mathrm{K}_{\mathrm{im}}=418.300 .000+34.425 .000$ $254.537 .000=452.725 .000 \quad-$ 254.537.000=Rp 198.188.000

Rata-rata keuntungan usaha ternak babi - ikan mujair :

$=\frac{198.188 .000}{30}=R p 6.606 .267 /$

responden

Berdasarkan hasil persamaan cdiatas maka keuntungan usaha ternak babi diintegrasikan dengan ikan mujair diwilayah penelitian sebesar Rp198.188.000/periode produksi, dengan rata-rata sebesar Rp.6.606.267/responden.

\section{KESIMPULAN}

Berdasarkan hasil penelitian dapat disimpulkan bahwa:

\section{DAFTAR PUSTAKA}

Blakely, J and D.H. Bade.2007. Ilmu Peternakan.Universitas Gajah Mada Press. Yogyakarta.

Rahardi, F; I. Satyawibaw, R. N. Setyowati. 2003. Agribisnis Peternakan. Cetakan Sembilan. PT Penebar Swadaya (Anggota IKAPI). Jakarta.

Rahardi, F. 2003. Agribisnis Perikanan. Penerbit Swadaya. Jakarta.

Soekartawi. 2002. Pembangunan Pertanian "Modernisasi" UI. Press. Jakarta.

Soekartawi, 2003. Teori Ekonomi Produksi, PT. Raja Grafindo Persada. Jakarta.
1. Besar keuntungan yang diperoleh dari usaha ternak babi di Kecamatan Sonder sebesar Rp 179.213.000/periode produksi atau dengan rata-rata sebesar Rp. 5.973.767/responden.

2. Besar keuntungan yang diperoleh dari usaha ikan mujair di Kecamatan Sonder sebesar Rp 18.975.000 dengan rata-rata sebesar Rp.632.500/responden.

3. Besar keuntungan yang diperoleh dari integrasi usaha ternak babi dengan ikan mujair di Kecamatan Sonder sebesar Rp 198.188.000/periode produksi atau dengan rata-rata sebesar Rp.6.606.267/responden.

Usaha ternak babi yang diintegrasikan dengan ikan mujair lebih menguntungkan dibandingkan dengan hanya mengusahakan ternak babi atau ikan mujair saja.

Sinaga, S. 2010. Bangsa Babi. http://blogs.unpad.ac.id/saulandsi naga

Sinaga, S. 2012. Perkandangan Babi. http://blogs.unpad.ac.id/saulandsi naga.

Santa, N. M, Masyhuri, S. Hartono, Suhardyastuti, 2011.Analisis Pengambilan Keputusan Pilihan Tujuan Usaha dan Ekonomi R. T. Tani Ternak Babi Di kabupaten Minahasa.

Singaribun, M. Effendi, S. 2011. Metode Penelitian Survei. LP3ES, Lembaga Penelitian, Pendidikan, Penerangan Ekonomi Dan Sosial. Jakarta.

Williamson, G. dan W.J.A. Payne. 2002. Pengantar peternakan di daerah tropis. Cetakan pertama. Terjemahan: S.G.N. Djiwa 
Jurnal Zootek ( “Zootek”Journal), Vol. 31 No. 1 : 1-10 (Juli 2013) ISSN 0852-2626

Darmadja. Gadjah Mada

University Press. Yogyakarta. 